\title{
Endovascular Embolization of Refractory Traumatic Carotid Cavernous Fistula with Micro-Coils: A Preliminary Experience
}

\author{
Refrakter Travmatik Karotikokavernöz Fistüllerin Mikrokoiller ile \\ Endovasküler Embolizasyonu: Ön Deneyim
}

\author{
Ziyin ZHANG ${ }^{1}$, Chaohua WANG ${ }^{2}$, Kun YANG ${ }^{1}$, Jianjian TANG ${ }^{1}$, Changwei ZHANG ${ }^{2}$, Xiaodong XIE ${ }^{2}$, Qifu LI ${ }^{3}$ \\ ${ }^{1}$ Affiliated Hospital of Hainan Medical College, Department of Neurosurgery, HaiKou, China \\ ${ }^{2}$ West China Hospital of Sichuan University, Department of Neurosurgery, ChengDu, China \\ ${ }^{3}$ Affiliated Hospital of Hainan Medical College, Department of Neurology, HaiKou, China
}

Corresponding Author: Xie XIAODONG / E-mail: xiaodong_1962@163.com

\begin{abstract}
AIM: This study reports our preliminary experiences in performing detachable micro-coils embolization for refractory traumatic carotid cavernous fistulas (TCCFs) and evaluates its efficacy and safety.

MATERIAL and METHODS: Fifteen consecutive patients with TCCFs treated with detachable micro-coils after initial failure of detachable balloons embolization are presented.

RESULTS: The fistulas were successfully occluded along with preservation of internal carotid artery (ICA) in 14 cases. However, the fistula and ICA were finally occluded with balloons in one case. The micro-coil got unraveled in one case, and the unraveled part had to be pulled into and fixed to the external carotid artery. All patients have undergone clinical and angiography follows up for a median duration of 22 months (range, 14 to 48 months). The clinical symptoms and signs related to fistulas such as proptosis, bruit, chemosis and headache gradually decreased after endovascular treatment in 14 cases, and only one case recurred after 2 weeks.

CONCLUSION: Micro-coils embolization is a safe and reliable strategy in refractory TCCFs that could not be managed by using detachable balloons. It may not be possible to densely pack the cavernous sinus, and subtotal packing also effectively occludes the fistula and alleviates the patient's symptoms.
\end{abstract}

KEYWORDS: Carotid-cavernous fistula, Micro-coil, Embolization, Superior ophthalmic vein

ÖZ

AMAÇ: Bu çalışma, refrakter travmatik karotikokavernöz fistüller (TCCF'ler) için ayrılabilir mikrokoil embolizasyonu yapmakla ilgili ön deneyiminizi bildirmekte ve etkinlik ve güvenliğini değerlendirmektedir.

YÖNTEM ve GEREÇLER: Başlangıçta ayrılabilir balon embolizasyonunun başarısız olmasından sonra ayrılabilir mikrokoiller ile tedavi edilen arka arkaya on beş TCCF hastası sunulmaktadır.

BULGULAR: Fistüller 14 olguda internal karotid arter (IKA) korumasıyla birlikte başarıyla tıkanmıştır. Ancak fistül ve IKA bir olguda son olarak balonlarla tıkanmıştır. Mikrokoil bir olguda açılmış ve açılan kısmın eksternal karotid arter içine çekilip burada sabitlenmesi gerekmiştir. Tüm hastalarda medyan 22 aylık (aralık, 14 - 48 ay) süre boyunca klinik ve anjiyografik takipleri yapılmıştır. Fistüllerle ilişkili proptosis, bruit, kemosis ve başağrısı gibi klinik bulgular ve belirtiler endovasküler tedaviden sonra 14 olguda giderek azalırken sadece bir olgu 2 haftadan sonra tekrarlamıştır.

SONUÇ: Mikrokoillerle embolizasyon, ayrılabilir balonlar kullanılarak tedavi edilemeyen refrakter TCCF'ler için güvenli ve güvenilir bir stratejidir. Kavernöz sinüsü yoğun bir şekilde doldurmak mümkün olmayabilir ama subtotal doldurma da fistülü etkin bir şekilde tıkar ve hastanın belirtilerini hafifletir.

ANAHTAR SÖZCÜKLER: Karotikokavernöz fistül, Mikrokoil, Embolizasyon, Süperior oftalmik ven

\section{INTRODUCTION}

Carotid cavernous fistulas (CCFs) are abnormal arteriovenous communications between the carotid artery or its branches and the cavernous sinus. Fundamentally, CCFs are classified as spontaneous or traumatic, direct or indirect, low-flow or high-flow. Compared with the spontaneous variety, traumatic carotid cavernous fistulas (TCCFs) are usually from direct shunting between the carotid artery and cavernous sinus with high flow and pressure. TCCFs, also known as type A CCF, usually present with exophthalmos, ocular pain, chemosis, and visual disturbances. They may occasionally result in lifethreatening epistaxis or intracranial hemorrhage (11). 
The ideal goal of management of TCCFs is occlusion of the fistula, while maintaining the ICA patency (2). Transarterial deployment of a detachable balloon through the fistula and into the cavernous sinus has become a well-established technique to occlude the fistula. However, the failure of transarterial balloon embolization may occur in $5 \%$ to $10 \%$ of cases (4). Recently, transarterial or transvenous microcoils embolization has been used for cases in which balloon embolization has failed (14). However, we found most of reports presented relatively low numbers of patients treated with micro-coils (mostly beneath ten patients), and these patients were treated with the concept of dense packing cavernous sinus (2). So we found it worthwhile to present our preliminary experiences in 15 cases of TCCFs treated with micro-coils, and to valuate its efficacy and safety.

\section{MATERIAL and METHODS}

\section{General Material}

From the 47 cases of TCCFs treated in West China Hospital between January 2007 and January 2010, a total of 15 patients of refractory TCCFs treated with micro-coils after failure of initial standard therapy were included in our study. The description of the patient population is summarized in Table I. There were 9 men and 6 women with a mean age of 42.4 years (range13-68 years). Patients had clinical presentations consisting of chemosis, proptosis, and cephalic bruit. This study only included patients with TCCFs in which balloon embolization failed.

\section{Endovascular Treatment}

\section{Transarterial approach}

The procedure was performed by femoral approach under general anesthesia $(n=11)$. Heparin boluses were given throughout the procedure for a target activated clotting time of a value of twice the baseline value. Slow intravenous nimodipine infusion was also implemented during the procedure to prevent possible intraoperative vasospasm. A
$6 \mathrm{~F}$ guiding catheter (Evoy, Cordis, Johnson \& Johnson Co., USA) was placed in the ipsilateral ICA. The micro-catheter was inserted into the cavernous sinus through the fistula tract under the guidance of road mapping. Then micro-coils were deployed in the cavernous sinus through the micro-catheter. Cerebral angiography was repeated sequentially after a coil was filled with checking for occlusion of the fistula. If the angiographic image shows faint persistent cavernous fistula and small-flow fistula, angiography was performed after 5-10 minutes. If the fistula was not visualized after this process, the operation was completed.

\section{Direct-puncture superior ophthalmic vein (SOV) approach}

The procedure was performed by direct puncture SOV approach under local anesthesia $(n=4)$. The method of systemic heparinization and nimodipine was the same as the transarterial approach. A $6 \mathrm{~F}$ guiding catheter (Evoy, Cordis, Johnson \& Johnson (o., USA) was placed in the ipsilateral ICA for repeated angiography and road mapping during the process of the endovascular treatment. Then, under local anesthesia to the upper part of the medial orbital angle proximal to the extraconal portion of the SOV, the SOV was directly punctured using an 18-gauge sheathed needle. After puncture of the SOV, the micro-catheter was negotiated along with the micro-guidewire (Tracker Excel 14, Boston Scientific, Freemont, CA) into the cavernous sinus. The process of deploying the micro-coils into the cavernous sinus was the same as the transarterial approach (Figure 1).

\section{RESULTS}

The average number of micro-coils was 5 (range, 2 16) and average length was $95 \mathrm{~cm}$ (range 12 186 cm). Complete fistula closures were documented on postoperation angiography in 14 TCCFs, in which 3 cases the fistulas with dense packing were immediately disappeared, the other 11 cases the fistulas with loosing packing were disappeared after waiting 5 10 minutes. However, large residual flow remained
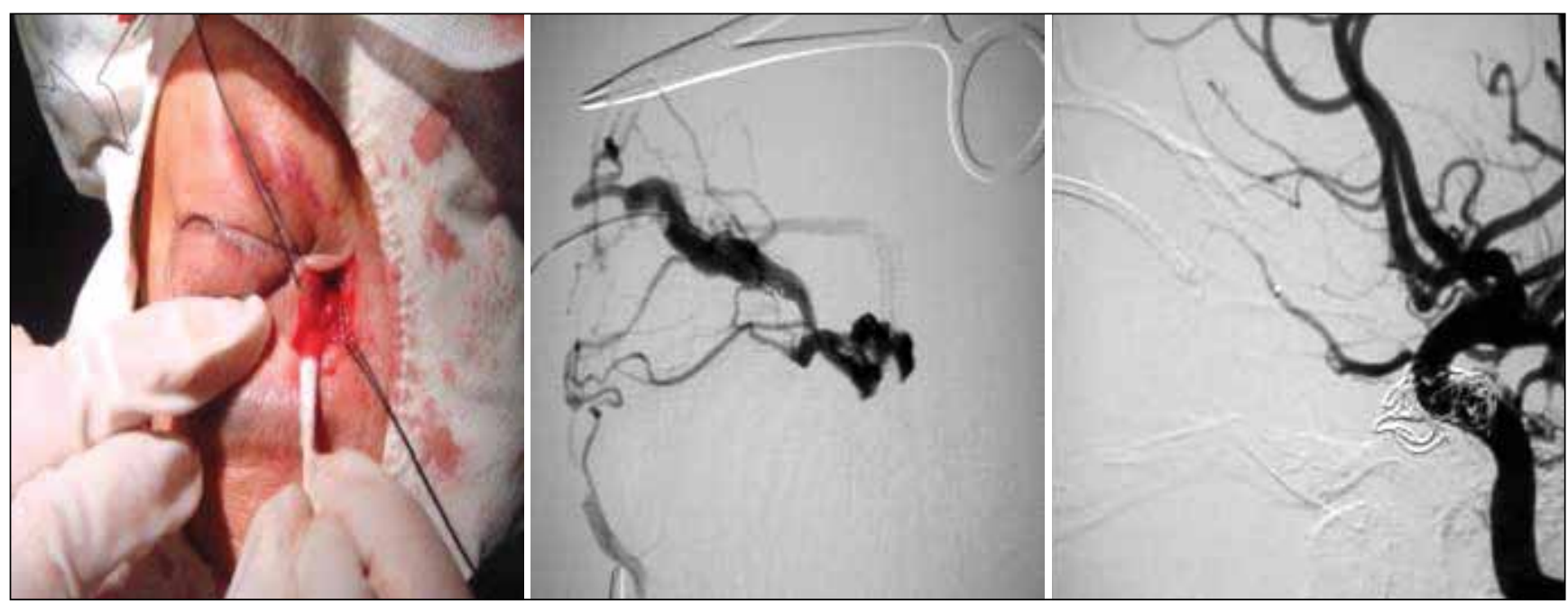

Figure 1: The embolization process via Direct-Puncture SOV approach. 
in the another case because of the inability of negotiating the micro-catheter into the fistula once separated after the successful deployment of 5 coils, and the fistula and parent artery were occluded with balloons after confirming that the balloon occlusion test (BOT test) was negative.

One patient experienced micro-coil unraveling. The unraveled part was pulled into the ipsilateral external carotid artery (ECA) and fixed (Figure $2 \mathrm{~A}-\mathrm{C}$ ). However, the fistula was completely occluded in spite of loose packing. In order to avoid the production of thrombosis, this patient was prescribed oral Clopidrogel (75 mg/day) and oral Aspirin (300mg/day) for a month and lifetime respectively. No permanent procedure-related neurological complication was observed in any of the 15 patients. All patients underwent clinical and angiography follow-up for a median duration of 22 months (range, 14 to 48 months); out of which the only one worthy of attention was the one mentioned above, in which the micro-coil was unraveled and revealed residual shunting with inferior petrosal sinus (IPS) drainage, long-term antithrombotic treatment being the cause of the recurrence
(Figure 2D). This was managed by deployment of a coil via the IPS pathway, negotiating a Hyperglide Balloon via the femoral arterial route to temporarily occlude the fistula, and finally injecting Onyx 18 into the cavernous sinus (Figure 2E$\mathrm{G})$. The clinical symptoms and signs related to fistula such as proptosis, bruit, chemosis and headache gradually decreased after endovascular treatment in the other 14 cases.

\section{DISCUSSION}

Because TCCFs usually present with severe clinical symptoms and show a significant risk of intracranial hemorrhage, the treatment must be urgent and effective. Surgery has a very limited role in treatment due to the high operative risk, significant morbidity and high recurrence rate. Conversely, endovascular embolization has become the primary treatment because it is relatively inexpensive, simple, and safe. The ideal goal of endovascular treatment is to occlude the site of communication between the ICA and the cavernous sinus while sparing the lumen of the ICA. Placing detachable balloons in the cavernous sinus by a transarterial route has
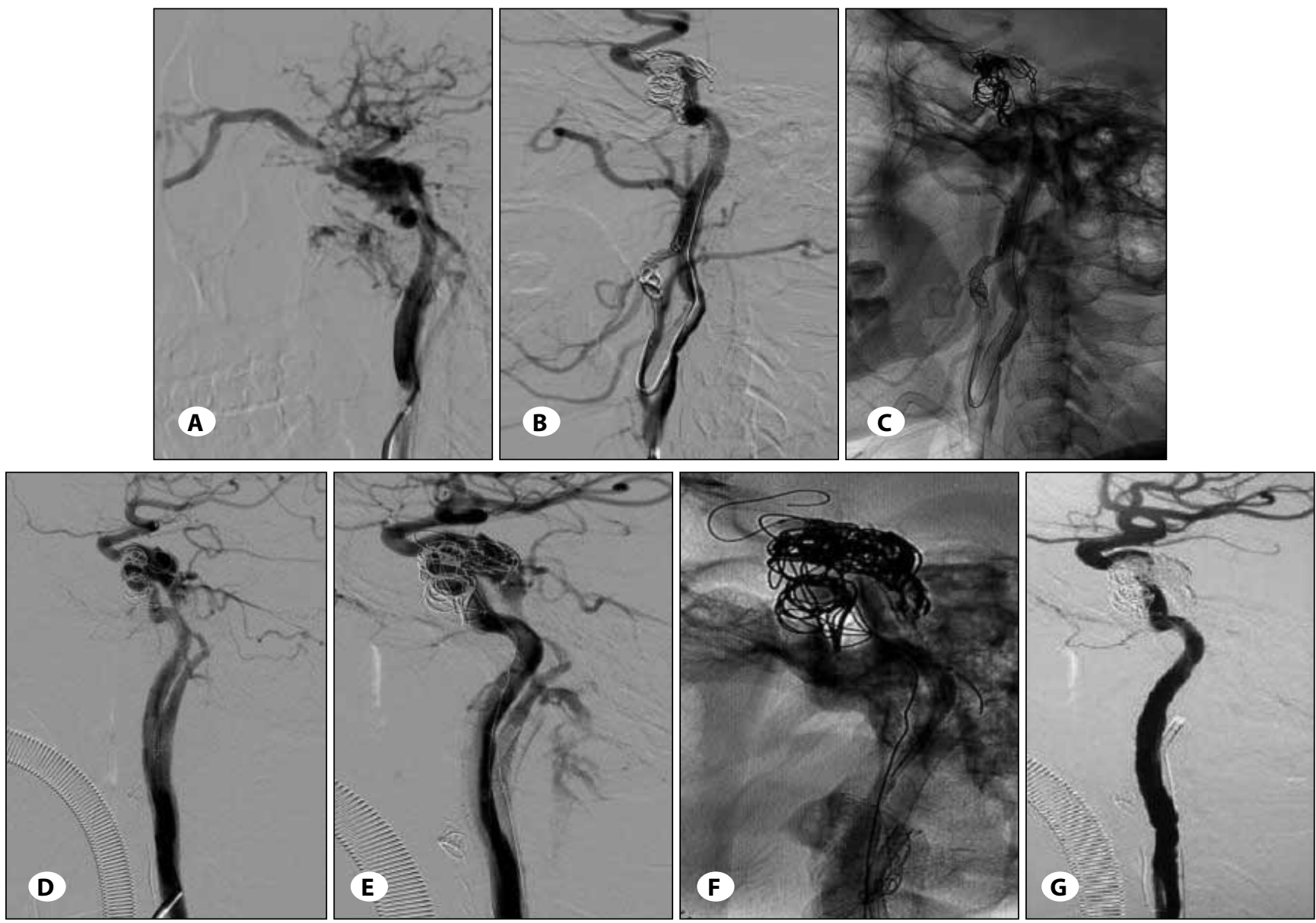

Figure 2: The embolization process of the only recurring case. A) The angiogram shows a TCCF, with drainage into SOV and IPS. B) The unraveled part had to be pulled into the ipsilateral external carotid artery and fixed, and the fistula was not existed. C) The fistula was completely occluded although it was loosely packed. D) Left ICA angiography revealed residual shunting with IPS drainage after 2 weeks. E-F) The recurred fistula was successfully embolized by micro-coils combined with Onyx-18. G) The post-embolization angiography revealed the fistula was occluded. 
Table I: Patient Demographics, Fistula Characteristics, Follow-Up, and Results

\begin{tabular}{|c|c|c|c|c|}
\hline $\begin{array}{l}\text { Case No. / } \\
\text { Age(years)/ } \\
\text { Sex }\end{array}$ & RITF & Approach & $\begin{array}{l}\text { Angiography } \\
\text { outcome }\end{array}$ & Follow-up (Months) and results \\
\hline $1 / 58 / F$ & $\begin{array}{l}\text { Balloon / micro- } \\
\text { catheter could not } \\
\text { enter the fistula }\end{array}$ & Transarterial & $\begin{array}{l}\text { Complete occlusion } \\
\text { with dense packing }\end{array}$ & $\begin{array}{l}\text { Complete occlusion of the fistula, good ICA } \\
\text { patency, total recovery at the 14-month } \\
\text { follow -up }\end{array}$ \\
\hline 2/22/M & $\begin{array}{l}\text { Multiple balloons } \\
\text { could not occlude } \\
\text { the fistula }\end{array}$ & Transarterial & $\begin{array}{l}\text { Complete occlusion } \\
\text { with dense packing }\end{array}$ & $\begin{array}{l}\text { Complete occlusion of the fistula, good ICA } \\
\text { patency, total recovery at the 42-month } \\
\text { follow-up }\end{array}$ \\
\hline $3 / 57 / M$ & $\begin{array}{l}\text { Multiple balloons } \\
\text { could not occlude } \\
\text { the fistula }\end{array}$ & Transarterial & $\begin{array}{l}\text { Complete occlusion } \\
\text { with loose packing }\end{array}$ & $\begin{array}{l}\text { Complete occlusion of the fistula, good ICA } \\
\text { patency, total recovery at the 18-month } \\
\text { follow-up }\end{array}$ \\
\hline $4 / 13 / F$ & $\begin{array}{l}\text { Early balloon } \\
\text { deflation }\end{array}$ & Transarterial & $\begin{array}{l}\text { Complete occlusion } \\
\text { with loose packing }\end{array}$ & $\begin{array}{l}\text { Complete occlusion of the fistula, good ICA } \\
\text { patency, total recovery at the 48-month } \\
\text { follow -up }\end{array}$ \\
\hline $5 / 68 / M$ & $\begin{array}{l}\text { Balloon ruptured on } \\
\text { mild inflation }\end{array}$ & Transarterial & $\begin{array}{l}\text { Complete occlusion } \\
\text { with loose packing }\end{array}$ & $\begin{array}{l}\text { Complete occlusion of the fistula, good ICA } \\
\text { patency, total recovery at the 18-month } \\
\text { follow -up }\end{array}$ \\
\hline $6 / 27 / M$ & $\begin{array}{l}\text { Early balloon } \\
\text { deflation }\end{array}$ & Transarterial & The fistula still exist & $\begin{array}{l}\text { The fistula and ICA were occluded with } \\
\text { balloons, total recovery at the 16-month } \\
\text { follow-up }\end{array}$ \\
\hline $7 / 45 / F$ & $\begin{array}{l}\text { Balloon could not } \\
\text { pass the stenosis } \\
\text { ICA }\end{array}$ & SOV & $\begin{array}{l}\text { Complete occlusion } \\
\text { with loose packing }\end{array}$ & $\begin{array}{l}\text { Complete occlusion of the fistula, good ICA } \\
\text { patency, total recovery at the 36-month } \\
\text { follow -up }\end{array}$ \\
\hline $8 / 56 / F$ & $\begin{array}{l}\text { Balloon / micro- } \\
\text { catheter could not } \\
\text { enter the fistula }\end{array}$ & Transarterial & $\begin{array}{l}\text { Complete occlusion } \\
\text { with loose packing. } \\
\text { The micro-coil } \\
\text { unraveled. }\end{array}$ & $\begin{array}{l}\text { The angiography revealed the fistula recurred } \\
\text { after } 2 \text { weeks, which was successfully occluded } \\
\text { with Onyx combined microcoils. Complete } \\
\text { occlusion of the fistula, good ICA patency, total } \\
\text { recovery at the 24-month follow-up. }\end{array}$ \\
\hline $9 / 65 / F$ & $\begin{array}{l}\text { Balloon could not } \\
\text { pass the tortuous } \\
\text { ICA }\end{array}$ & SOV & $\begin{array}{l}\text { Complete occlusion } \\
\text { with loose packing }\end{array}$ & $\begin{array}{l}\text { Complete occlusion of the fistula, good ICA } \\
\text { patency, total recovery at the } 22 \text {-month } \\
\text { follow-up. }\end{array}$ \\
\hline $10 / 23 / M$ & $\begin{array}{l}\text { Multiple balloons } \\
\text { could not occlude } \\
\text { the fistula }\end{array}$ & Transarterial & $\begin{array}{l}\text { Complete occlusion } \\
\text { with dense packing }\end{array}$ & $\begin{array}{l}\text { Complete occlusion of the fistula, good ICA } \\
\text { patency, total recovery at the 16-month } \\
\text { follow-up }\end{array}$ \\
\hline $11 / 34 / \mathrm{M}$ & $\begin{array}{l}\text { Balloon ruptured on } \\
\text { mild inflation }\end{array}$ & SOV & $\begin{array}{l}\text { Complete occlusion } \\
\text { with loose packing }\end{array}$ & $\begin{array}{l}\text { Complete occlusion of the fistula, good ICA } \\
\text { patency, total recovery at the } 27 \text {-month } \\
\text { follow-up }\end{array}$ \\
\hline $12 / 29 / F$ & $\begin{array}{l}\text { Early balloon } \\
\text { deflation }\end{array}$ & Transarterial & $\begin{array}{l}\text { Complete occlusion } \\
\text { with loose packing }\end{array}$ & $\begin{array}{l}\text { Complete occlusion of the fistula, good ICA } \\
\text { patency, total recovery at the 18-month } \\
\text { follow-up }\end{array}$ \\
\hline $13 / 37 / M$ & $\begin{array}{l}\text { Balloon / micro- } \\
\text { catheter could not } \\
\text { enter the fistula }\end{array}$ & Transarterial & $\begin{array}{l}\text { Complete occlusion } \\
\text { with loose packing }\end{array}$ & $\begin{array}{l}\text { Complete occlusion of the fistula, good ICA } \\
\text { patency, total recovery at the 16-month } \\
\text { follow -up }\end{array}$ \\
\hline $14 / 59 / F$ & $\begin{array}{l}\text { Balloon could not } \\
\text { pass the tortuous } \\
\text { ICA }\end{array}$ & Transarterial & $\begin{array}{l}\text { Complete occlusion } \\
\text { with loose packing }\end{array}$ & $\begin{array}{l}\text { Complete occlusion of the fistula, good ICA } \\
\text { patency, total recovery at the 18-month } \\
\text { follow-up }\end{array}$ \\
\hline 15/43/M & $\begin{array}{l}\text { Multiple balloons } \\
\text { could not occlude } \\
\text { the fistula }\end{array}$ & SOV & $\begin{array}{l}\text { Complete occlusion } \\
\text { with loose packing }\end{array}$ & $\begin{array}{l}\text { Complete occlusion of the fistula, good ICA } \\
\text { patency, total recovery at the 32-month } \\
\text { follow-up }\end{array}$ \\
\hline
\end{tabular}

RITF, reasons for initial treatment failure. 
become the standard treatment for TCCFs at present and results in low morbidity and mortality. There are occasions, however, when detachable embolization is not feasible. This technique may fail, for example, if sharp bony fragments or foreign bodies rupture the balloon during inflation, if the tear in the vessel wall is too small to allow the passage of a balloon, or if the ICA is too narrow / tortuous to navigate a balloon into the cavernous sinus $(5,12,15,18)$. In the circumstances described above, placing detachable micro-coils in the cavernous sinus is an effective alternative management for TCCFs, either by a transarterial or transvenous approach. In contrast to a detachable balloon, the micro-coils are easy to retrieve, reposition, and exchange, if so required.

At present, most scholars advocate that the cavernous sinus should be densely packed in order to achieve complete blockage of the shunting flow with angiography cure of the TCCFs $(2,8,20)$. However, it was a fortuitously observed that the fistula was entirely occluded with loose packing by placing 3 micro-coils. So, as long as angiographic imaging revealed that faint persistent cavernous sinus and low-flow fistula in the later cases were observed, the micro-coils were not placed in the cavernous fistula temporarily, and angiography was repeatedly performed after 5 10 minutes. The next angiography revealed the residual fistulae was spontaneous closed in the other 10 patients. This phenomenon can be explained with the positive role of hemodynamic of the TCCFs, which is quite different from that of intracranial aneurysms. It is thought that a thrombus is more easily induced by microcoils owing to a decrease in blood flow passing through the fistula secondary to a decrease in blood pressure during general anesthesia. Another reason may be the relation to vascular spasm caused by the contrast medium. Spontaneous resolution of direct TCCFs by thrombosis of the cavernous sinus has been previously described in many reports $(1,7,18)$, which strongly supports our viewpoint. Though the fistula of one case recurred in our group, the most likely cause should be long term anti-thrombotic therapy rather than loose packing. Therefore, subtotal occlusion with small residual shunting flow may not indicate failure of embolization, and also does not appear to be a definite indication to place more coils. However, a follow-up angiogram is necessary to check the occurrence of spontaneous thrombosis.

In the literature, it is difficult to find a consistent viewpoint concerning proper antithrombotic treatment measures after the procedure of micro-coils embolization. Recommendations range from no antithrombotic therapy to full heparinization or double antiplatelet therapy (9). Bink et al. (3) encouraged that all patients should implement a strict antithrombotic measure, in order to avoid post-interventional thrombosis of the ophthalmic vein due to slow flow in enlarged draining veins after closure of the fistula. Recent studies have shown that specific attention must be paid to antithrombotic medications as excessive bleeding, including epidural hematoma formation may occur with interventional techniques when antithrombotic therapy is continued. Hence, rapid assessment and immediate surgical or nonsurgical intervention should be performed to avoid permanent neurological complications $(10,17)$. However, long term antithrombotic increased the recurrence rate because it is not conducive to thrombosis of the cavernous sinus, particular in patients with loose packing. In our series, the patient recurred precisely because of longterm antithrombotic treatment. Hence, we recommend that it is not necessary to implement antithrombotic treatment if the fistula is occluded with micro-coils alone or coils-related thromboembolic complications have not occurred.

Micro-coil unraveling and stretching is a rare and serious device-related complication caused by repeatedly adjusting the position of the micro-coils $(6,19,22)$. If the micro-coil cannot be retrieved completely, the loose end of the microcoil floating in the ICA may prolapse into the distal part of the ICA and cause brain infarction. In our group, this complication occurred only in one case. The measure implemented in this case was to pull out and fix the unraveled part into the external carotid artery, which fortunately proved to be a rather simple, effective and safe option to prevent occlusion of the ICA. The embolization via SOV is an important alternative method for the refractory TCCFs, which were unsuccessfully treated when the transarterial approach has failed or is unavailable $(13,21)$. As with any approach, there are also some complications with the direct surgical SOV approach $(13,23)$. They include risk of damage to the trochlea or other orbital structures, causing retroocular infection and hemorrhage. The ocular signs and symptoms will also result in a very heavy psychological burden on patients and their relatives. Nevertheless, during the process there is always a huge risk of rupturing of the SOV, resulting in relatively unstoppable bleeding and consequent formation of orbital hematoma and loss of visual acuity. We therefore had to delay treatment for about three months in four patients, waiting for the SOV walls and lumen to grow thicker and bigger respectively. Furthermore, being a very delicate procedure, it had to be maneuvered very gently and precisely.

\section{CONCLUSION}

In our series, all of the patients were successfully treated with detachable micro-coils, either by a transarterial or transvenous approach. This method proved both safe and effective in the management of these refractory TCCFs, which could not be successfully embolized with detachable balloons. It may not be possible to densely pack the cavernous sinus, but subtotal packing also effectively occludes the fistula and alleviates the patient's symptoms. However, the inadequacies of this study are that the number of cases is inadequate and long-term follow-up must be performed in future studies.

\section{ACKNOWLEDGEMENTS}

This study was supported by a grant from the West China Hospital of Sichuan University. 


\section{REFERENCES}

1. Alkhani A, Willinsky $R$, Terbrugge K: Spontaneous resolution of bilateral traumatic carotid cavernous fistulas and development of transsellar intercarotid vascular communication: Case report. Surg Neurol 52: 627-629,1999

2. Bavinzski G, Killer M, Gruber A, Richling B: Treatment of posttraumatic carotico-cavernous fistulae using electrolytically detachable coils: Technical aspects and preliminary experience. Neuroradiology 39: 81-85,1997

3. Bink A, Berkefeld J, Lüchtenberg M, Gerlach R, NeumannHaefelin T, Zanella F: Coil embolization of cavernous sinus in patients with direct and dural arteriovenous fistula. Eur Radiol 19:1443-1449,2009

4. Chen LZ, Xu MH, Yang DH, Zhou YW, Zhang YD: Retrospective study on the endovascular embolization for traumatic carotid cavernous fistula. Chin J Traumatol 13: 20-24, 2010

5. Debrun G, Vinuela F, Fox A, Davis K, Ahn H: Indications for treatment and classification of 132 carotid-cavernous fistulas. Neurosurgery 22: 285-289,1988

6. Dinc H, Kuzeyli K, Kosucu P, Sari A, Cekirge S: Retrieval of prolapsed coils during endovascular treatment of cerebral aneurysms. Neuroradiology 48:269-272,2006

7. Ferrera PC: Traumatic carotid-cavernous sinus fistula with spontaneous resolution. Am J Emerg Med 15: 386-388, 1998

8. Guglielmi G, Viñuela F, Duckwiler G, Dion J, Stocker A: High-flow, small-hole arteriovenous fistulas: Treatment with electrodetachable coils. AJNR Am J Neuroradiol 16: 325-328,1995

9. Gupta AK, Purkayastha S, Krishnamoorthy T, Bodhey NK, Kapilamoorthy TR, Kesavadas C: Endovascular treatment of direct carotid cavernous fistulae: A pictorial review. Neuroradiology 48: 831-839, 2006

10. Gwyn J, Shinton R: Spontaneous cervical epidural haematoma: Role of antiplatelets. JRSM Short Rep 3:20, 2012

11. Hayashi, Suyama K, Nagata I: Traumatic carotid cavernous fistula complicated with intracerebral hemorrhage: Case report. Neurol Med Chir 51:214-216,2011

12. Higashida R, Halbach V, Tsai FY: Interventional neurovascular treatment of traumatic carotid and vertebral artery lesions: Results in 234 cases. AJR Am J Roentgenol 153: 577-582,1989
13. Kurata A, Suzuki S, Lwamoto K, Miyazaki T, Lnukai M, Abe K: Direct-puncture approach to the extraconalportion of the superior ophthalmic vein for carotid cavernous fistula. Neuroradiology 51: 755-759, 2009

14. Li J, Lan ZG, Xie XD, You C, He M:Traumatic carotid-cavernous fistulas treated with covered stents: Experience of 12 cases. World Neurosurg 73:514-519, 2010

15. Luo CB, Teng MM, Yen DH, Chang FC, Lirng JF, Chang CY: Endovascular embolization of recurrent traumatic carotidcavernous fistulas managed previously with detachable balloons. J Trauma 56:1214-1220,2004

16. Marden FA, Roy SS, Malisch TW: A novel approach to direct carotid cavernous fistula repair: HydroCoil-assisted revision after balloon reconstruction. Surg Neurol 64:140-143,2005

17. Manchikanti L, Falco FJ, Benyamin RM, Caraway DL, Kaye AD, Helm li $S$, et al: Assessment of bleeding risk of interventional techniques: A best evidence synthesis of practice patterns and perioperative management of anticoagulant and antithrombotic therapy. Pain Physician 16:SE261-SES318, 2013

18. Nishijima M, Lwai R, Horie Y, Oka N, Takaku A: Spontaneous occlusion of traumatic carotid cavernous fistula after orbital venography. Surg Neurol 23: 489-492,1985

19. Standard SC, Chavis TD, Wakhloo AK, Ahuja A, Guterman LR, Hopkins LN: Retrieval of Guglielmi detachable coil after unravelling and fracture: Case report and experimental results. Neurosurgery 35: 994-998,1994

20. Siniluoto T, Seppänen S, Kuurne T, Wikholm G, Leinonen $S$, Svendsen P: Transarterial embolization of a direct carotid cavernous fistula with Guglielmi detachable coils. AJNR Am J Neuroradiol 18: 519-523,1997

21. Wang ZG, Ding X, Zhang JQ, Qu CC, Wang CW, Huang DZ, Hao X; Hydrocoil occlusion for treatment of traumatic carotid-cavernous fistula: Preliminary experience. Eur J Radiol 71: 456-460, 2009

22. Wang $\mathrm{CH}$, Xie XD: Treatment of an unraveled intracerebral coil. Catheter Cardiovasc Interv 76:746-750,2010

23. White JB, Layton KF, Evans AJ, Tong FC, Jensen ME, Kallmes DF: Transorbital puncture for the treatment of cavernous sinus dural fistulas. AJNR Am J Neuroradiol 28:1415-1417,2007 